\title{
Araștırma Makalesi/Research Article \\ Şırnak İli İdil ilçesinde Yetiştirilen Üzüm Çeşitlerinin Bazı Ampelografik Özellikleri
}

\author{
Mehmet Settar Ünal $^{1^{*} \quad \text { Murat Yıldırım }}{ }^{2}$ \\ ${ }^{1}$ Şırnak Üniversitesi, Ziraat Fakültesi, Bahçe Bitkileri Bölümü, Şırnak \\ 2 Şırnak Üniversitesi, Fen Bilimleri Enstitüsü, Bahçe Bitkileri ABD, Şırnak \\ *Sorumlu yazar:munal62@ hotmail.com \\ ${ }^{1}$ https://orcid.org/0000-0001-5903-0157, ${ }^{2}$ https://orcid.org/0000-0001-9982-4621
}

Geliș Tarihi: 22.07.2019

Kabul Tarihi: 09.01.2020

\section{Öz}

2017-2018 yıllarında yapılan bu çalışmada, Şırnak ili idil ilçesinde yetiştirilen 20 üzüm çeşidine ait yıllık dal, çiçek salkımı, meyve salkım, tane ve çekirdek özellikleri olmak üzere toplam 28 karakter incelenmiş ve çalışmalar çiçeklenme ve dinlenme döneminde yürütülmüştür. İncelemeye alınan özelliklerin değerlendirilmesinde IBPGR, OIV ve UPOV tarafindan hazırlanan ve 1983 yılında yayınlanan 'Descriptors for Grape' adlı yayın ile 1989 yılında yayınlanan 'Minimal Descriptor List for Grapevine Varieties' adlı yayından yararlanılmıştır. Çubukta; enine kesit ve ana rengi, Çiçek salkımında; çiçek yapısı, ilk salkımın çıktığı boğum, göz başına düşen salkım sayısı, Meyve salkımında; salkım sapı boyu, salkım büyüklüğü, salkım boyu ve salkım sıklığg, salkım sapı odunlaşması, Tanede; tane boyu, tane eni ve ağırlığı, irilikte ve renkte birörneklik, tane şekli ve tane rengi, tane kabuk kalınlığı, tane sapı boyu, şıra randımanı, şırada SÇKM ve asitlik, olgunluk indisi ve pH, Çekirdekte; çekirdek ağırlığı, çekirdek eni ve çekirdek boyu incelenmiş, inceleme sonucunda tüm çeşitler çekirdekli bulunurken diğer tüm özellikler farklı gruplarda yer almışlardır.

Anahtar Kelimeler: Bağcılık, üzüm, ampelografi, Şırnak, İdil

\section{Some Ampelographic Characteristics of Grape Varieties Grown in Idil District of Sirnak Province}

\section{Abstract}

In this study conducted in during flowering and harvesting period in 2017-2018, a total of 28 characters of 20 grape varieties grown in the Idil district of Sirnak province were examined. Descriptors for Grape (1983) and Minimal Descriptor List for Grapevine Varieties (1989) prepared by IBPGR, OIV and UPOV were used for the evaluation of the features. In vine canes; cross section and main color, In flower clusters; flower type, the node emerging from the first cluster, the number of clusters per bud, In fruit clusters; cluster stalk length, cluster size, cluster length, cluster compactness, In berry; berry size, berry width and berry weight, uniformity in size and color, berry shape and berry color, berry shell thickness, berry stalk length, must yield, TSS and acidity in must, maturity index and $\mathrm{pH}$, In seed; seed weight, seed width and seed length were examined.

Keyword: Viticulture, grape, ampelography, Sirnak, Idil

\section{Giriş}

Dünyada; Vavilov tarafından belirlenen 8 gen merkezi arasında olan Ülkemizin, yürütülen arkeolojik çalışmalara ve elde edilen bulgulara göre 5000 y1lı aşan bir bağc1lık kültürü olduğu tespit edilmiştir (Şehirali ve Özgen, 1987).

Vitis vinifera ssp. sativa; Vitis cinsi içerisinde yer alan 32 türün en önemlisi olup, dünyada yetiştiriciliği yapılan üzüm çeşitlerinin \%90'dan daha fazlasını içermektedir (Ünal, 2000).

Ülkemiz toplam üretim alanı $4.170 .410 \mathrm{da}$, üretim miktar1 3.933 .000 ton olup, bu üretimin \% 49.5'i sofralık, \% 38.7'si kurutmalık ve \% 11,8'i ise şaraplık-şıralık olarak değerlendirilmektedir.

Çalışmanın yürütüldüğü İdil yöresinde ise aynı değerler sırayla 19.067 da ve 10.449 tondur (Anonim, 2019). Ancak elde edilen ürünün oran olarak değerlendirme şekline dair resmi bir veri ise bulunamamıştır. İlçe, Süryanilerin yoğun olarak yaşadığı dönemlerde bağları ile ün kazanmıştır.

Bağcılığın yoğun iş gücü istemesine karşılık, terör olayları başta olmak üzere değişik sebeplerden dolayı üreticilerin bağa olan ilgisi azalmış, bunun sonucunda da bağ alanları yavaş yavaş terk edilmiştir. Ancak ekolojik şartlar itibarı ile bağcılığa uygun olan yörede bağc1lığın geliştirilmesi ve hak ettiği yeri alabilmesi için bazı tedbirlerin alınması gereklidir. 
$\mathrm{Bu}$ çalışma ile önemli bir bağcılık potansiyeline sahip olan ilçede yetiştiriciliği yapılan üzüm çeşitlerini tespit ve muhafaza etmek, uluslararası normlara göre tanımlayarak bir standardizasyona ulaşmak suretiyle yörede kurulacak yeni bağlarla modern bağcılığın canlanmasına hizmet etmek ve yapılacak diğer çalışmalara ışık tutmak amaçlanmıştır.

\section{Materyal ve Metot}

$\mathrm{Bu}$ araştırmada, materyal olarak Şırnak ili İdil ilçesinde yetiştirilen üzüm çeşitleri kullanılmıştır. 2017-18 yıllarında hasat döneminde yörede yetiştirilen üzüm çeşitlerinin belirlenmesi amacıyla İlçe Tarım ve Orman Müdürlüğü ile yazışmalar yapılmış; yöre bağcılığı ve yetiştirilen üzüm çeşitleri hakkında bilgi edinilmiş; bu bilgiler 1şığı altında bağ bölgelerine gidilerek yetiştiricilerle ayrıntılı bir şekilde görüşülerek alınan bilgiler kaydedilmiştir. Bu şekilde yerinde belirlenen çeşitlerin değişik veya aynı bağda olmak üzere sağlıklı ve verimli omcalarından yeterli (10 adet) sayıda işaretlenerek etiketlenmiş ve krokisi çıkarılmıştır.

Araştırmada; İdil ilçesine bağlı köylerde yaygın olarak yetiştiriciliği yapılan Mazrone, Mısabık, Bahdo, Bakari, Şikari, Kerküş, Raşe kewnar (Gewdone), Raşe gurnık, Zeynebi, Zeyti, Hasani, Beytilhamam, Zerine, Bılbızeki, Gewre, Payizi, Tayifi (Beleki), Nasiri, Sinceri ve Goglani olmak üzere toplam 20 üzüm çeşidi 2 yıl boyunca ayrıntılı olarak incelenmiştir.

Çalışmada; yöntem birliği sağlamak ve olabilecek karışıklıkları gidermek için "Descriptors for Grape" adlı 'Üzüm Tanımlayıcıları" esas alınmış (Anonim, 1983), aynı zamanda 5. Uluslararası sempozyumda yayınlanan 'Minimal Descriptor List for Grapevine Varieties' adlı bir diğer 'Üzüm Tanımlayıcıları'ndan da yararlanılmıştır (Anonim, 1989).

Yöntemde; OIV, UPOV ve IBPGR 'Üzüm Tanımlayıcıları'nda yer alan ampelografik özellikleri ile bu özelliklerin açıklamaları esas alınmış; üzüm çeşitlerinin fotoğrafları verilmiş; özelliklerin verilişinde konular benzerliklerine göre sınıflandırılmış; numunelerin alınma yerleri, alınma zamanları ve miktarları ile incelenen özellikler OIV kod numaralarına göre verilmiştir (Çizelge $1)$.

$\mathrm{Bu}$ çalışmada; tane kabuk rengi gözlem yoluyla, tane kabuk kalınlı̆̆ 1 (3 kişilik bir ekip tarafindan) tatma yoluyla, tane eni ve boyu, tane sap boyu, çekirdek en ve boy ölçümleri ise dijital kumpas yardımıyla laboratuvarda gerçekleştirilirken, ilk çiçek salkımının çıktığı boğum, sürgün üzerindeki salkım sayısı, çiçek yapısı, salkım sıklı̆̆, salkım sapı odunlaşması, tane büyüklügünde ve rengindeki bir örneklik, çubuk rengi, çekirdek varlığı, meyve salkımının eni ve boyu, meyve salkımı sapı boyu gibi özellikler ise arazi çalışmaları ile belirlenmiştir.

Çalışmada incelenen çeşitlerin suda çözünebilir kuru madde, $\mathrm{pH}$, olgunluk indisi, asitlik ve şıra randımanlarının tespiti için her bir çeşide ait omcaların değişik yerlerinden alınan yaklaşık 1 kg'lık örneğin laboratuvarda bir bez torba içerisinde sıkılarak şıraları çıkarılmıştır. Elde edilen şıraların suda çözünebilir kuru madde oranı refraktometre; asit miktarları tartarik asit cinsinden "titrasyon yöntemi" pH değerleri pH metre yardımı ile belirlenirken şıra randımanı ölçü silindiri ile ölçülmüştür.

Çalışmada incelenen üzüm çeşitlerinin olgunluk zamanına göre sınıflandırılmasında ise Kara (1990)'dan faydalanılmıştır.

Bunun yanı sıra salkım büyüklüğü ve meyve eti sertliği gibi özelliklerin sınıf aralığı değerlerinin belirlenmesinde Uzun (1986)'dan, yaprakların salamuraya uygunluğunu belirtmede Ünal (2018)'den yararlanılmıştır. Yine $\mathrm{pH}$ ve olgunluk indislerine sadece tartışma kısmında yer verilmiştir.

Tane şekli, yıllık dalın enine kesiti ve ana rengi laboratuvarda Anonim (1983) ve Anonim (1989)' da belirtilen özellikler ile karşılaştırılarak belirlenmiştir.

Çalışmada ele alınan üzüm çeşitlerinin arazi çalışmaları sırasında toplanan salkım ve yaprak numunelerinin bozulmasını önlemek için buzluk termos içerisinde laboratuvara getirilmiştir.

Yapılan çalışmada incelenen üzüm çeşitlerinin yıllık dal, çekirdek ve veri değerlendirmeleri asmaların dinlenme döneminde; hasat ise Ağustos, Eylül ve Ekim aylarında yapılmıştır.

\section{Bulgular ve Tartışma}

Bütün çeşitlerde koruk dönemindeki yeşil renk, ben düşme ile beraber çeşide has bir şekilde değişmiştir. Tane kabuk rengi incelenen Bakari, Bılbızeki, Zerine, Payizi, Şikari, Sinceri, Gawre, 
Beytilhamam, Hasani, Zeyti, Zeynebi, Nasiri, Bahdo, Goglani, Kerküş ve Mazrone çeşitlerin hepsinde "yeşil sarı"; Raşe gurnık, Raşe kewnar ve Mısabık çeşitlerinde "'Siyah"; Tayifi (Beleki) çeşidi ise "'koyu kırmız mor'" olarak gözlenmiştir. Her ne kadar tane rengi çeşide has ise de rengin yoğunluk ve bir örnekliğinin aynı omcada bile farklılık göstermesi, birçok faktörün bu özelliğin oluşumunda etken olduğunu göstermektedir.

İncelenen çeşitlerin yıllık dal (çubuk) ana renkleri ağırlıklı olarak "sarımsı kahverengi" olmakla birlikte "kırmızımsı-kahverengi" ve farklı tonları görülmüştür.

İncelenen çeşitlerde çubukların enine kesiti 12 çeşitte 'yuvarlak' 6 çeşitte 'Basık oval' 2 çeşitte ise 'oval' olarak belirlenmiş olup, bu tespit Kara (1990), Altın (1991), Gürsöz (1993), Dilli (1997) ve Ünal (2000)'ın araştırma bulguları ile de desteklenmektedir.

Anonim (2001)'e göre dört tip asma çiçeği olduğu bildirilmekle beraber incelenen çeşitlerde çiçek yapısı Gawre ve Hasani'de 'Morfolojik erdişi fizyolojik dişi', diğer çeşitlerde "Erdişi”" olarak belirlenmiş; 'Morfolojik erdişi fizyolojik dişi' çiçek tipinin tüm çeşitler içerisinde \% 10 oranına sahip olduğu bulunmuştur. Bu oranın, Dursun (1994)'un çalışmasında \% 7.7; Aktepe (1994)' in çalışmasında \%28.6 civarında bulunmuş olması mevcut çeşitlerimiz içerisinde dişi çiçek yapısına sahip çeşitlerin önemsenmeyecek kadar bir sayıya sahip olduklarını göstermektedir. Ayrıca diğer meyve türlerinden farklı olarak asmada çiçek tomurcuğunun açılması üstten değil, alttan olmaktadır.

Sürgün başına salkım/göz sayısı 7 çeşitte " $0-1$ salkım", 10 çeşitte "1.1-2 salkım" 3 çeşitte ise '2.1-3 Salkım' sınıfında yer almıştır. İlk çiçek salkımının çıktığı boğum incelendiğinde 5 çeşidin "'1. ve 2. Boğum"; 8 çeşidin " 3 . ve 4. Boğum"; geriye kalan 7 çeşidin ise " 5 . Boğum ve Yukarısı" sınıfında yer aldıkları gözlenmiştir. Gerek terbiye şekli seçiminde gerekse de budama yöntemi hakkında bizlere ön bilgi vermesi bakımından bu bulgular oldukça önemlidir.

Üzüm çeşitlerinde salkım boyu, "çok kısa-uzun" sınıfında sıralanmış olup 1 çeşit "çok kısa”, 6 çeşit "orta", 13 çeşit ise "kısa" grubunda yer almıştır. Çeşit tespitinde önceleri önemli bir kıstas olarak bilinen salkım boyu; toprak tipi ve yapısı, sulama, terbiye sistemi, budama yöntemi, dalda birakılan göz sayısı, kimyasal madde uygulaması, iklim şartları vb. sebeplerden dolayı salkım farklılıkları oluştuğundan eski değerini yitirmiştir (Morton, 1979).

IBPGR, Salkım büyüklügünü "enxboy” olarak kabul ederken Kara (1990) ve Gürsöz (1993), enxboy hesaplanmasında özellikle omuzlu, kanatlı ve konik bir yapıda olan çeşitlerde salkımın dışında kalan alanında ölçümde yer alması bazı hatalı sonuçlara neden olacağını düşündüklerinden sağlıklı olmayacağı kanaatine varmışlardır. İncelenen çeşitler salkım büyüklügü olarak ise "çok küçük-büyük" sınıfında yer almış olup, 3 çeşit "büyük", 4 çeşit "orta", 6 çeşit "çok küçük" ve 7 çeşit "küçük" grubunda bulunmuştur.

Çeşitlerin salkım sapı uzunluğu bakımından 1'er çeşit "uzun-çok kısa", 4 çeşit "orta" ve 14 çeşit "kısa" grubunda yer almışlardır. Bu hal bir çeşit özelliği olması yanında kültürel uygulamalar, iklim şartları, özellikle çiçeklenme dönemindeki kötü hava şartlarıyla birlikte çiçek yapısıyla da yakından ilişkili olduğu bilinmektedir. Nitekim Calo ve ark. (1991) yaptıkları çalışmada, salkım büyüklüğü ve salkım ağırlı̆̆ı, salkım sapı boyu, kuru madde ve asit gibi özellikler üzerinde çevresel faktörlerin büyük etkisi olduğunu vurgulamışlardır.

Yöresel çeşitlerde tane şekli bakımından farkl11ıklar görülmüştür. Bir çeşitte veya omcada tane şeklinin çevre şartlarından fazla etkilenmemesi bu karakterin çeşit belirlemedeki önemini göstermektedir. Bununla beraber tane şeklinin tozlayıcı çeşide göre değişebileceği de belirtilmektedir. Özbek (1951), tozlayıcı çeşidin tane boyu ve eni üzerine etkisi bulunmadığını bildirirken, Dağlı (1962) ve Fidan (1975) ise tozlayıcıların tane şekillerini etkileyebileceğini ifade etmişlerdir. Tane şekli bakımından çeşitlerden 1'ri "sivri", 7'si "elips", 12'si ise "yuvarlak" olarak tespit edilmiştir.

Çalışmada incelenen çeşitlere ait saf bağların olmaması nedeniyle dekara verim tespit edilememiştir. Tane ağırlığı açısından 1'er çeşit "çok hafif-hafif", 2 çeşit "'çok ağır", 5 çeşit "ağır " ve 11 çeşit "orta" ağır olarak tespit edilmiştir.

Üzümün değerlendirme şekli ve kalite gibi özelliklerine etki eden şırada suda çözünebilir kuru madde oranı bakımından 7 çeşidin "orta", 5 çeşidin "düşük", 5 çeşidin 'yüksek", geriye kalan çeşitlerin ise "çok yüksek" sınıfında yer aldıkları belirlenmiştir.

Çeşitlerin şırada asit oranları bakımından ise 11 çeşit "düşük", 6 çeşit "orta" ve 3 çeşit "yüksek" grubunda yer almışlardır. Bu durum çeşitler arasındaki genetik farklılıklara ilaveten 
Kara'nın (1990) da belirttiği gibi çevre ve bakım işlemlerindeki farklılıklar sebebiyle her yıl hasadın aynı zamanda yapılamamasından da kaynaklanabilmektedir.

Araştırmamızda, tam olgunlukta şırada $\mathrm{pH}$ değerleri çeşitler arasında farklılık göstermiştir. Winkler ve ark., (1974) oluma kadar pH'nın önemli derecede arttığını, pH'daki bu değişim ile yeme kalitesindeki uygusuz tadların kaybolduğunu ve değiştiğini bildirmişlerdir. Cooke ve Berg (1983) Kaliforniya'da şaraplık üzümlerde yaptıkları araştırmada beyaz çeşitlerde şırada pH'nın 3.0-3.5, siyah çeşitlerde ise 3.1-3.6 arasında değiştiğini bildirmişlerdir. Bu çalışmada ise 3.52 ile Raşe kewnar en düşük, 4.31 ile Hasani çeşidi en yüksek değeri gösterirken diğer çeşitler bu iki değer arasında sıralanmışlardır. Bilhassa sıcak bölgelerde üzümlerin olgunluk kriteri olarak $\mathrm{pH}$ derecesi de önerilmektedir (Fanizza, 1982). Özdemir ve Bayhan (2018)'de Diyarbakır ili Çermik ve Eğil ilçelerinde 2011 yılında yürüttükleri bir çalışmada Şire (Mazrone) çeşidinin pH değeri 3.74 bulunurken bu çalışmada 3.66 olarak bulunmuş olup, aradaki farklılığın çevre şartları ve kültürel işlemler vb.den kaynaklandığı düşünülmektedir.

Tat bakımından incelenen bütün çeşitler özelliksiz olarak tespit edilirken tane sap uzunluğu olarak ise Raşe gurnık ve Mısabık çeşitleri "çok kısa", diğer çeşitler ise "kısa" sınıfında yer almışlardır.

Hasat zamanının belirlenmesi ve salkımın dala bağlanmasında büyük bir önem arz eden salkım sapı odunlaşması bakımında 1'er çeşit “yok-zayıf", 8'er çeşit ise "orta-güçlü" sınıfında tespit edilmiştir.

İncelenen çeşitlerin çekirdek boyu bakımından 1 çeşit “orta”, 7 çeşit "çok uzun” ve 12 çeşit "uzun" olarak tespit edilmiştir.

Çekirdek eni açısından 1 çeşit "orta geniş", 3 çeşit "geniş", 16 çeşit de "çok geniş" sınıfında tespit edilmiştir.

Çekirdek ağırlı̆̆ı olarak; 9 çeşit “orta ağır”, 7 çeşit "ağır”, 4 çeşit ise "ç̧ok ağır” grubunda yer almışlardır. Çekirdeklerin tane büyüklüğü yanı sıra tane şeklini de etkilediği bildirilmektedir (Barış ve Gürnil, 1991). Genellikle iri ve ağır tanelerin çekirdekleri de ağır olurken, uzun tanelerdeki çekirdeklerin de uzun oldukları dikkat çekmiştir.

Bölgede incelenen çeşitlerin tamamı çekirdekli olarak tespit edilmiştir. Üzüm taneleri normal olarak 4 adet'e kadar çekirdek oluşturabilmekle beraber genellikle incelenen çeşitlerin 2-3 adet çekirdek içerdiği gözlenmiştir. Oraman (1959), kurutulmuş halde iken çekirdeğin şekil, renk, parlaklık, şalaza'nın yeri ve büyüklügü bakımından kimi çeşitlerde farklılıklar gösterdiğini bildirmiştir. Fidan (1985)'a göre çekirdeğin tanelerinin bileşimi ve gelişimi üzerinde önemli bir etkisi bulunmaktadır. İncelenen çeşitlere ait özellikler (Çizelge 1.) ve fotoğraflar (Şekil1-20)'de verilmiştir.

Çizelge 1. Üzüm Çeşitlerinde İncelenen Organlara İlişkin Ampelografik Bulgular

\begin{tabular}{|c|c|c|c|c|c|c|}
\hline OIV & $\begin{array}{l}\text { İncelenen } \\
\text { Özellikler }\end{array}$ & Bakari & Bilbizeki & Zerine & Raşe gürnik & Raşe kewnar \\
\hline Kod No & Çubuk Öz. & \multicolumn{5}{|c|}{ Dinlenme Döneminde 10 Çubukta Boğum ve Boğum aralarında İncelenen Özellikler } \\
\hline 101 & Enine Kesit & Yuvarlak & Basık Oval & Oval & Basık Oval & Yuvarlak \\
\hline \multirow[t]{2}{*}{103} & Ana Renk & Sar. Kah. & Kahverengi & Sarıms1 & Sarı. Kah. & Kahverengi \\
\hline & Çiçek Salkımı Öz. & \multicolumn{5}{|c|}{ Çiçeklenme Döneminde 10 Salkımda Belirlenen Özellikler } \\
\hline 151 & Çiçek Yapısı & Erdişi & Erdişi & Erdişi & Erdişi & Erdişi \\
\hline 152 & $\begin{array}{l}\text { İlk Salkımın } \\
\text { Çıktığı Boğum } \\
\end{array}$ & $\begin{array}{l}\text { 5. Boğum ve } \\
\text { Yukarısı }\end{array}$ & $\begin{array}{l}\text { 5. Boğum ve } \\
\text { Yukarısı }\end{array}$ & 3-4.Boğum & 3-4. Boğum & $\begin{array}{l}\text { 5. Boğum ve } \\
\text { Yukarısı }\end{array}$ \\
\hline \multirow[t]{2}{*}{153} & Salkım/Göz & 0-1.Salkım & 0-1.Salkım & 2.1-3.Salkım & 1.1-2.Salkim & 1.1-2.Salkım \\
\hline & Meyve Salkım Öz. & \multicolumn{5}{|c|}{ Derim Döneminde 10 Salkımda Belirlenen Özellikler } \\
\hline 202 & $\begin{array}{l}\text { Salkım Büyüklüğü } \\
\left(\mathrm{cm}^{2}\right)\end{array}$ & $\begin{array}{l}\text { Küçük } \\
(162.35 \pm 11.8) \\
\end{array}$ & $\begin{array}{l}\text { Küçük } \\
(188.1 \pm 12.83) \\
\end{array}$ & $\begin{array}{l}\text { Küçük } \\
(161.05 \pm 16.73)\end{array}$ & $\begin{array}{l}\text { Çok Küçük } \\
(108.9 \pm 8.36) \\
\end{array}$ & $\begin{array}{l}\text { Çok Küçük } \\
(124.4 \pm 9.19) \\
\end{array}$ \\
\hline 203 & Salkım Boyu (cm) & $\begin{array}{l}\text { Orta } \\
(19.75 \pm 0.60)\end{array}$ & $\begin{array}{l}\text { Uzun } \\
(20.55 \pm 0.73)\end{array}$ & $\begin{array}{l}\text { Kisa } \\
(16.85 \pm 1.24)\end{array}$ & $\begin{array}{l}\text { Kisa } \\
(13.40 \pm 0.64)\end{array}$ & $\begin{array}{l}\text { Kisa } \\
(14.25 \pm 0.61)\end{array}$ \\
\hline 204 & Salkım Sıklığı & Sik & Orta & Sik & Çok Sık & Orta Sik \\
\hline 206 & $\begin{array}{l}\text { Salkım Sap1 } \\
\text { Uzunluğu(cm) }\end{array}$ & $\begin{array}{l}\text { K1sa } \\
(4.55 \pm 0.41)\end{array}$ & $\begin{array}{l}\text { K1sa } \\
(4.4 \pm 0.42) \\
\end{array}$ & $\begin{array}{l}\text { Orta } \\
(7.25 \pm 0.37)\end{array}$ & $\begin{array}{l}\text { K1sa } \\
(4.0 \pm 0.45) \\
\end{array}$ & $\begin{array}{l}\text { Kisa } \\
(5.05 \pm 0.79)\end{array}$ \\
\hline \multirow[t]{2}{*}{207} & Sap Odunlaşması & Zayif & Orta & Orta & Güçlü & Güçlü \\
\hline & Tane Öz. & \multicolumn{5}{|c|}{ Derim Döneminde 10 Salkımdan Alınan 40 Tanede Incelenen Özellikler } \\
\hline $221-1$ & Boy $(\mathrm{mm})$ & $\begin{array}{l}\text { Uzun } \\
(18.59 \pm 0.14) \\
\end{array}$ & $\begin{array}{l}\text { Uzun } \\
(18.76 \pm 0.17)\end{array}$ & $\begin{array}{l}\text { Orta } \\
(16.87 \pm 0.13)\end{array}$ & $\begin{array}{l}\text { Uzun } \\
(19.49 \pm 0.32)\end{array}$ & $\begin{array}{l}\text { Uzun } \\
(19.59 \pm 0.19)\end{array}$ \\
\hline
\end{tabular}


ÇOMÜ Zir. Fak. Derg. (COMU J. Agric. Fac.)

2020: 8 (1): 61-72

ISSN: 2147-8384 / e-ISSN: 2564-6826

doi: $10.33202 /$ comuagri.595158

\begin{tabular}{|c|c|c|c|c|c|c|}
\hline $221-2$ & $\operatorname{En}(\mathrm{mm})$ & $\begin{array}{l}\text { Orta } \\
(17.07 \pm 0.19)\end{array}$ & $\begin{array}{l}\text { Orta } \\
(15.59 \pm 0.16)\end{array}$ & $\begin{array}{l}\text { Orta } \\
(16.01 \pm 0.17)\end{array}$ & $\begin{array}{l}\text { Orta } \\
(17.16 \pm 0.23)\end{array}$ & $\begin{array}{l}\text { Orta } \\
(15.79 \pm 0.19)\end{array}$ \\
\hline 222 & İrilikte Bir örneklik & Bir Örnek Değil & Bir Örnek Değil & Birörnek Değil & Birörnek Değil & Birörnek Değil \\
\hline 223 & Tanenin Şekil & Yuvarlak & Yuvarlak & Yuvarlak & Elips & Elips \\
\hline 225 & Kabuk Rengi & Yeşil-Sarı & Yeşil-Sarı & Yeşil-Sarı & Siyah & Siyah \\
\hline 226 & $\begin{array}{l}\text { Kabuk Rengi } \\
\text { Bir örneklik }\end{array}$ & Bir Örnek & Bir Örnek & Birörnek & Bir Örnek & Bir Örnek \\
\hline- & Kabuk Kalınlığ & İnce & İnce & Kalın & Orta & İnce \\
\hline 233 & Şıra Randımanı(\%) & Düşük (52.90) & Orta (55.10) & Orta (60.00) & Orta (57.50) & Yüksek (65.00) \\
\hline 238 & $\begin{array}{l}\text { Tane Sap } \\
\text { Boyu }(\mathrm{mm})\end{array}$ & $\begin{array}{l}\text { Kisa } \\
(6.59 \pm 0.16)\end{array}$ & $\begin{array}{l}\text { K1sa } \\
(6.84 \pm 0.21)\end{array}$ & $\begin{array}{l}\text { Kisa } \\
(6.74 \pm 0.16)\end{array}$ & $\begin{array}{l}\text { Çok Kısa } \\
(5.87 \pm 0.21)\end{array}$ & $\begin{array}{l}\text { Kisa } \\
(6.61 \pm 0.23)\end{array}$ \\
\hline 241 & Çekirdek Varlığ 1 & Var & Var & Var & Var & Var \\
\hline 503 & Tane Ağırlığı(g) & $\begin{array}{l}\text { Orta } \\
(3.47 \pm 0.08)\end{array}$ & $\begin{array}{l}\text { Orta } \\
(3.26 \pm 0.08)\end{array}$ & $\begin{array}{l}\text { Orta } \\
(3.04 \pm 0.07)\end{array}$ & $\begin{array}{l}\text { Orta } \\
(3.46 \pm 0.13)\end{array}$ & $\begin{array}{l}\text { Orta } \\
(3.69 \pm 0.11)\end{array}$ \\
\hline 505 & SÇKM (\%) & Orta(19.40) & Yüksek(20.50) & Orta(18.60) & Yüksek(22.10) & Orta(20.10) \\
\hline 506 & Asitlik $\{\mathrm{g} / \mathrm{l})$ & Düşük(6) & Orta (9) & Düşük(6) & Orta(7.50) & Yüksek(9) \\
\hline- & Olgunluk İndisi (\%) & 32.33 & 22.77 & 31.00 & 29.46 & 22.33 \\
\hline \multirow[t]{2}{*}{-} & $\mathrm{pH}$ & 3.74 & 3.80 & 4.10 & 3.58 & 3.52 \\
\hline & Çekirdek Öz. & \multicolumn{5}{|c|}{ Örnek Olarak Alınan Tanelerden Çıkarllan 40 Çekirdekte Belirlenen Özellikler } \\
\hline $242-1$ & Boy $(\mathrm{mm})$ & $\begin{array}{l}\text { Uzun } \\
(7.30 \pm 0.06)\end{array}$ & $\begin{array}{l}\text { Uzun } \\
(6.68 \pm 0.06)\end{array}$ & $\begin{array}{l}\text { Uzun } \\
(6.86 \pm 0.04)\end{array}$ & $\begin{array}{l}\text { Çok Uzun } \\
(7.51 \pm 0.08)\end{array}$ & $\begin{array}{l}\text { Çok Uzun } \\
(8.39 \pm 0.09)\end{array}$ \\
\hline $242-2$ & $\operatorname{En}(\mathrm{mm})$ & $\begin{array}{l}\text { Çok Enli } \\
(4.36 \pm 0.06)\end{array}$ & $\begin{array}{l}\text { Enli } \\
(3.81 \pm 0.08)\end{array}$ & $\begin{array}{l}\text { Enli } \\
(4.02 \pm 0.03)\end{array}$ & $\begin{array}{l}\text { Çok Enli } \\
(4.76 \pm 0.06)\end{array}$ & $\begin{array}{l}\text { Çok Enli } \\
(5.0 \pm 0.05)\end{array}$ \\
\hline 243 & Ağırlık(mg) & $\begin{array}{l}\text { Çok Ağır } \\
(72.3 \pm 0.001)\end{array}$ & $\begin{array}{l}\text { Orta } \\
(51.40 \pm 0.001)\end{array}$ & $\begin{array}{l}\text { Orta } \\
(57.3 \pm 0.001)\end{array}$ & $\begin{array}{l}\text { Çok A ğır } \\
(74.5 \pm 0.001)\end{array}$ & $\begin{array}{l}\text { Orta } \\
(57.60 \pm 0.01)\end{array}$ \\
\hline
\end{tabular}

Çizelge 1. Üzüm Çeşitlerinde İncelenen Organlara İlişkin Ampelografik Bulgular (devam)

\begin{tabular}{|c|c|c|c|c|c|c|}
\hline OIV & $\begin{array}{l}\text { İncelenen } \\
\text { Özellikler }\end{array}$ & Payizi & Şikari & Sinceri & Gawre & Nasiri \\
\hline Kod No & Çubuk Öz. & \multicolumn{5}{|c|}{ Dinlenme Döneminde 10 Çubukta Boğum ve Boğum aralarında İncelenen Özellikler } \\
\hline 101 & Enine Kesit & Yuvarlak & Basık Oval & Yuvarlak & Yuvarlak & Oval \\
\hline \multirow[t]{2}{*}{103} & Ana Renk & Sar1 & Sar. Kah. & Sarı & Sarı. Kah. & Kah. Kır. \\
\hline & $\begin{array}{l}\text { Çiçek Salkımı } \\
\text { Öz. }\end{array}$ & \multicolumn{5}{|c|}{ Çiçeklenme Döneminde 10 Salkımda Belirlenen Özellikler } \\
\hline 151 & Çiçek Yapısı & Erdişi & Erdişi & Erdişi & Dişi & Erdişi \\
\hline 152 & $\begin{array}{l}\text { İlk Salkımın } \\
\text { Çıktı̆̆ı Boğum }\end{array}$ & $\begin{array}{l}\text { 5. Boğum ve } \\
\text { Yukarısı }\end{array}$ & 3-4. Boğum & 1-2.Boğum & 3-4. Boğum & 1-2. Boğum \\
\hline \multirow[t]{2}{*}{153} & Salkım/Göz & 1.1-2.Salkım & 0-1. Salkım & 0.1.Salkım & 0-1.Salkım & 1.1-2.Salkım \\
\hline & $\begin{array}{l}\text { Meyve Salkım } \\
\text { Öz. }\end{array}$ & \multicolumn{5}{|c|}{ Derim Döneminde 10 Salkımda Belirlenen Özellikler } \\
\hline 202 & $\begin{array}{l}\text { Salkım } \\
\text { Büyüklüğ̈̈ }\left(\mathrm{cm}^{2}\right)\end{array}$ & $\begin{array}{l}\text { Orta } \\
(246.60 \pm 36.30)\end{array}$ & $\begin{array}{l}\text { Büyük } \\
(292.98 \pm 24.28)\end{array}$ & $\begin{array}{l}\text { Çok Küçük } \\
(92.80 \pm 11.75)\end{array}$ & $\begin{array}{l}\text { Küçük } \\
(166.550 \pm 18.80)\end{array}$ & $\begin{array}{l}\text { Küçük } \\
(150.93 \pm 11.46)\end{array}$ \\
\hline 203 & Salkım Boyu (cm) & $\begin{array}{l}\text { Orta } \\
(18.4 \pm 0.98)\end{array}$ & $\begin{array}{l}\text { Orta } \\
(19.45 \pm 0.74)\end{array}$ & $\begin{array}{l}\text { Kisa } \\
(12.85 \pm 0.64)\end{array}$ & $\begin{array}{l}\text { Kisa } \\
(17.20 \pm 1.39)\end{array}$ & $\begin{array}{l}\text { Kisa } \\
(16.05 \pm 0.46)\end{array}$ \\
\hline 204 & Salkım S1klığı & Orta Sik & Sik & Sik & Orta Sik & Seyrek \\
\hline 206 & $\begin{array}{l}\text { Salkım Sap } \\
\text { Uzunluğu(cm) }\end{array}$ & $\begin{array}{l}\text { Orta } \\
(6.7 \pm 0.62)\end{array}$ & $\begin{array}{l}\text { Uzun } \\
(8.25 \pm 0.72)\end{array}$ & $\begin{array}{l}\text { Kisa } \\
(3.85 \pm 0.47)\end{array}$ & $\begin{array}{l}\text { Kisa } \\
(4.5 \pm 0.51)\end{array}$ & $\begin{array}{l}\text { K1sa } \\
(4.7 \pm 0.30)\end{array}$ \\
\hline \multirow[t]{2}{*}{207} & Sap Odunlaşması & Yok & Orta & Orta & Güçlü & Güçlü \\
\hline & Tane Öz. & \multicolumn{5}{|c|}{ Derim Döneminde 10 Salkımdan Alınan 40 Tanede İncelenen Özellikler } \\
\hline $221-1$ & $\operatorname{Boy}(\mathrm{mm})$ & $\begin{array}{l}\text { Uzun } \\
(19.08 \pm 0.17)\end{array}$ & $\begin{array}{l}\text { Uzun } \\
(19.77 \pm 0.16)\end{array}$ & $\begin{array}{l}\text { Orta } \\
(17.25 \pm 0.12)\end{array}$ & $\begin{array}{l}\text { Uzun } \\
(18.45 \pm 0.15)\end{array}$ & $\begin{array}{l}\text { Çok Uzun } \\
(22.27 \pm 0.25)\end{array}$ \\
\hline $221-2$ & $\operatorname{En}(\mathrm{mm})$ & $\begin{array}{l}\text { Enli } \\
(18.65 \pm 0.23)\end{array}$ & $\begin{array}{l}\text { Enli } \\
(19.57 \pm 0.17)\end{array}$ & $\begin{array}{l}\text { Orta } \\
(17.07 \pm 0.12)\end{array}$ & $\begin{array}{l}\text { Enli } \\
(19.07 \pm 0.20)\end{array}$ & $\begin{array}{l}\text { Enli } \\
(19.41 \pm 0.27)\end{array}$ \\
\hline 222 & $\begin{array}{l}\text { İrilikte Bir } \\
\text { örneklik } \\
\end{array}$ & Bir Örnek Değil & Birörnek & Birörnek & Birörnek Değil & Birörnek Değil \\
\hline 223 & Tanenin Şekil & Yuvarlak & Yuvarlak & Yuvarlak & Yuvarlak & Elips \\
\hline 225 & Kabuk Rengi & Yeşil-Sarı & Yeşil-Sarı & Yeşil-Sarı & Yeşil-Sarı & Yeşil-Sarı \\
\hline 226 & $\begin{array}{l}\text { Kabuk Rengi } \\
\text { Bir örneklik }\end{array}$ & Bir Örnek Değil & Birörnek & Birörnek & Bir Örnek & Birörnek Değil \\
\hline- & Kabuk Kalınlı̆̆ & İnce & İnce & İnce & İnce & İnce \\
\hline 233 & $\begin{array}{l}\text { Şıra } \\
\text { Randımanı(\%) }\end{array}$ & Düşük (54.50) & Düşük (52.60) & Düşük (53.30) & Orta (58.00) & Orta $(59.00)$ \\
\hline 238 & $\begin{array}{l}\text { Tane Sap } \\
\text { Boyu(mm) }\end{array}$ & $\begin{array}{l}\text { Kisa } \\
(7.16 \pm 0.20)\end{array}$ & $\begin{array}{l}\text { Kisa } \\
(6.85 \pm 0.22) \\
\end{array}$ & $\begin{array}{l}\text { Kisa } \\
(6.30 \pm 0.12)\end{array}$ & $\begin{array}{l}\text { Kisa } \\
(7.02 \pm 0.23)\end{array}$ & $\begin{array}{l}\text { Kisa } \\
(6.93 \pm 0.23)\end{array}$ \\
\hline
\end{tabular}


ÇOMÜ Zir. Fak. Derg. (COMU J. Agric. Fac.)

2020: 8 (1): 61-72

ISSN: $2147-8384$ / e-ISSN: 2564-6826

doi: 10.33202/comuagri.595158

\begin{tabular}{|c|c|c|c|c|c|c|}
\hline 241 & Çekirdek Varlığ & Var & Var & Var & Var & Var \\
\hline 503 & Tane Ağırlığı(g) & $\begin{array}{l}\text { Ağır } \\
(4.51 \pm 0.15)\end{array}$ & $\begin{array}{l}\text { A ğır } \\
(4.83 \pm 0.11)\end{array}$ & $\begin{array}{l}\text { Orta } \\
(3.16 \pm 0.06)\end{array}$ & $\begin{array}{l}\text { Ağır } \\
(4.50 \pm 0.11)\end{array}$ & $\begin{array}{l}\text { Çok Ağır } \\
(5.76 \pm 0.19)\end{array}$ \\
\hline 505 & SÇKM (\%) & Orta(17.90) & Düşük(17.10) & Orta $(19.80)$ & Orta(18.60) & Yüksek(23.40) \\
\hline 506 & Asitlik $\{\mathrm{g} / \mathrm{l})$ & Düşük(6) & $\operatorname{Orta}(8)$ & Düşük (6) & Düşük (6) & Düşük (6) \\
\hline- & $\begin{array}{l}\text { Olgunluk İndisi } \\
(\%)\end{array}$ & 29.83 & 21.37 & 33.00 & 31.00 & 39.00 \\
\hline \multirow[t]{2}{*}{-} & $\mathrm{pH}$ & 3.69 & 3.76 & 3.61 & 3.85 & 4.22 \\
\hline & Çekirdek Öz. & \multicolumn{5}{|c|}{ Örnek Olarak Alınan Tanelerden Çıkarılan 40 Çekirdekte Belirlenen Özellikler } \\
\hline $242-1$ & Boy $(\mathrm{mm})$ & $\begin{array}{l}\text { Çok Uzun } \\
(7.69 \pm 0.07) \\
\end{array}$ & $\begin{array}{l}\text { Uzun } \\
(7.01 \pm 0.05)\end{array}$ & $\begin{array}{l}\text { Uzun } \\
(7.23 \pm 0.04)\end{array}$ & $\begin{array}{l}\text { Çok Uzun } \\
(7.45 \pm 0.06)\end{array}$ & $\begin{array}{l}\text { Çok Uzun } \\
(7.43 \pm 0.09) \\
\end{array}$ \\
\hline $242-2$ & $\operatorname{En}(\mathrm{mm})$ & $\begin{array}{l}\text { Çok Enli } \\
(4.08 \pm 0.05)\end{array}$ & $\begin{array}{l}\text { Çok Enli } \\
(4.44 \pm 0.04)\end{array}$ & $\begin{array}{l}\text { Çok Enli } \\
(4.49 \pm 0.04)\end{array}$ & $\begin{array}{l}\text { Çok Enli } \\
(4.16 \pm 0.06)\end{array}$ & $\begin{array}{l}\text { Çok Enli } \\
(4.20 \pm 0.08) \\
\end{array}$ \\
\hline 243 & Ağırlık(mg) & $\begin{array}{l}\text { Ağır } \\
(63.70 \pm 0.001)\end{array}$ & $\begin{array}{l}\text { Ağır } \\
(65.40 \pm 0.002)\end{array}$ & $\begin{array}{l}\text { Ağır } \\
(60.70 \pm 0.001)\end{array}$ & $\begin{array}{l}\text { Ağır } \\
(61.90 \pm 0.001)\end{array}$ & $\begin{array}{l}\text { Orta } \\
(57.20 \pm 0.002)\end{array}$ \\
\hline
\end{tabular}

Çizelge 1. Üzüm Çeşitlerinde İncelenen Organlara İlişkin Ampelografık Bulgular (devam)

\begin{tabular}{|c|c|c|c|c|c|c|}
\hline OIV & $\begin{array}{l}\text { İncelenen } \\
\text { Özellikler }\end{array}$ & Beytilhamam & Goglani & Kerküş & Hasani & Tayifi \\
\hline Kod No & Çubuk Öz. & \multicolumn{5}{|c|}{ Dinlenme Döneminde 10 Çubukta Boğum ve Boğum aralarında İncelenen Özellikler } \\
\hline 101 & Enine Kesit & Yuvarlak & Basık Oval & Yuvarlak & Yuvarlak & Yuvarlak \\
\hline \multirow[t]{2}{*}{103} & Ana Renk & Kah. Sarıms1 & Açık Kah. & Kırmızı Kah. & Koyu Kah. & Kırmızımsı Kah. \\
\hline & Çiçek Salkımı Öz. & \multicolumn{5}{|c|}{ Çiçeklenme Döneminde 10 Salkımda Belirlenen Özellikler } \\
\hline 151 & Çiçek Yapısı & Erdişi & Erdişi & Erdişi & Dişi & Erdişi \\
\hline 152 & $\begin{array}{l}\text { İlk Salkımın } \\
\text { Çıktığı Boğum }\end{array}$ & $\begin{array}{l}\text { 5. Boğum ve } \\
\text { Yukarısı }\end{array}$ & 3-4. Boğum & 3-4.Boğum & 1-2. Boğum & 1-2. Boğum \\
\hline \multirow[t]{2}{*}{153} & Salkım/Göz & 1.-3. Salkım & 0-1. Salkım & 1.1-2. Salkım & 1.1-2.Salkım & 1.1-2. Salkım \\
\hline & Salkım Öz. & \multicolumn{5}{|c|}{ Derim Döneminde 10 Salkımda Belirlenen Özellikler } \\
\hline 202 & $\begin{array}{l}\text { Salkım Büyüklüğü } \\
\left(\mathrm{cm}^{2}\right)\end{array}$ & $\begin{array}{l}\text { Çok Küçük } \\
(67.4 \pm 10.31)\end{array}$ & $\begin{array}{l}\text { Küçük } \\
(176.15 \pm 12.14)\end{array}$ & $\begin{array}{l}\text { Orta } \\
(246.03 \pm 12.17)\end{array}$ & $\begin{array}{l}\text { Büyük } \\
(286.08 \pm 17.5)\end{array}$ & $\begin{array}{l}\text { Orta } \\
(207.70 \pm 8.97)\end{array}$ \\
\hline 203 & Salkım Boyu (cm) & $\begin{array}{l}\text { Çok Kısa } \\
(10.4 \pm 0.59)\end{array}$ & $\begin{array}{l}\text { Kisa } \\
(12.7 \pm 0.41)\end{array}$ & $\begin{array}{l}\text { Orta } \\
(18.35 \pm 0.92)\end{array}$ & $\begin{array}{l}\text { Orta } \\
(19.10 \pm 0.54)\end{array}$ & $\begin{array}{l}\text { Kisa } \\
(16.10 \pm 0.55)\end{array}$ \\
\hline 204 & Salkım Sıklığı & Sik Değil & Orta Sik & Orta Sik & Sik & Sik \\
\hline 206 & $\begin{array}{l}\text { Salkım Sap } \\
\text { Uzunluğu(cm) }\end{array}$ & $\begin{array}{l}\text { Kisa } \\
(5.15 \pm 0.46)\end{array}$ & $\begin{array}{l}\text { Orta } \\
(6.4 \pm 1.02)\end{array}$ & $\begin{array}{l}\text { K1sa } \\
(5.65 \pm 0.25)\end{array}$ & $\begin{array}{l}\text { Kisa } \\
(5.05 \pm 0.30)\end{array}$ & $\begin{array}{l}\text { Kisa } \\
(4.15 \pm 0.28)\end{array}$ \\
\hline 207 & Sap Odunlaşması & Güçlü & Güçlü & Orta & Orta & Güçlü \\
\hline & Tane Öz. & \multicolumn{5}{|c|}{ Derim Döneminde 10 Salkumdan Alınan 40 Tanede Incelenen Özellikler } \\
\hline $221-1$ & Boy(mm) & $\begin{array}{l}\text { Orta } \\
(15.35 \pm 0.25)\end{array}$ & $\begin{array}{l}\text { Uzun } \\
(18.58 \pm 0.18)\end{array}$ & $\begin{array}{l}\text { Uzun } \\
(19.19 \pm 1.50)\end{array}$ & $\begin{array}{l}\text { Uzun } \\
(18.85 \pm 0.17)\end{array}$ & $\begin{array}{l}\text { Çok Uzun } \\
(21.93 \pm 0.217)\end{array}$ \\
\hline $221-2$ & $\mathrm{En}(\mathrm{mm})$ & $\begin{array}{l}\text { Orta } \\
(15.56 \pm 0.23)\end{array}$ & $\begin{array}{l}\text { Orta } \\
(16.69 \pm 0.18)\end{array}$ & $\begin{array}{l}\text { Dar } \\
(13.91 \pm 0.20)\end{array}$ & $\begin{array}{l}\text { Orta } \\
(16.82 \pm 0.15)\end{array}$ & $\begin{array}{l}\text { Enli } \\
(17.78 \pm 0.18)\end{array}$ \\
\hline 222 & İrilikte Bir örneklik & Birörnek Değil & Birörnek Değil & Birörnek & Birörnek & Birörnek Değil \\
\hline 223 & Tanenin Şekil & Yuvarlak & Elips & Elips & Yuvarlak & Elips \\
\hline 225 & Kabuk Rengi & Yeşil-Sarı & Yeşil-Sarı & Yeşil-Sarı & Yeşil-Sarı & $\begin{array}{l}\text { Koyu Kırmızı } \\
\text { Mor }\end{array}$ \\
\hline 226 & $\begin{array}{l}\text { Kabuk Rengi } \\
\text { Bir örneklik }\end{array}$ & Birörnek Değil & Birörnek Değil & Birörnek & Birörnek & Birörnek Değil \\
\hline- & Kabuk Kalınlığ1 & Kalın & İnce & İnce & İnce & Orta \\
\hline 233 & Şıra Randımanı(\%) & Yüksek (65.40) & Orta $(56.10)$ & Orta (61.00) & $\begin{array}{l}\text { Çok Yüksek } \\
(78.20)\end{array}$ & Orta $(62.00)$ \\
\hline 238 & $\begin{array}{l}\text { Tane Sap } \\
\text { Boyu(mm) }\end{array}$ & $\begin{array}{l}\text { Kisa } \\
(6.32 \pm 0.22)\end{array}$ & $\begin{array}{l}\text { K1sa } \\
(6.75 \pm 0.28)\end{array}$ & $\begin{array}{l}\text { K1sa } \\
(7.48 \pm 0.29)\end{array}$ & $\begin{array}{l}\text { Kısa } \\
(6.49 \pm 0.20)\end{array}$ & $\begin{array}{l}\text { K1sa } \\
(7.62 \pm 0.34)\end{array}$ \\
\hline 241 & Çekirdek Varlığ1 & Var & Var & Var & Var & Var \\
\hline 503 & Tane Ağırlığı(g) & $\begin{array}{l}\text { A ğır } \\
(4.09 \pm 0.26)\end{array}$ & $\begin{array}{l}\text { Orta } \\
(3.42 \pm 0.09)\end{array}$ & $\begin{array}{l}\text { Orta } \\
(2.80 \pm 0.09) \\
\end{array}$ & $\begin{array}{l}\text { Orta } \\
(3.48 \pm 0.10) \\
\end{array}$ & $\begin{array}{l}\text { Ağır } \\
(4.66 \pm 0.12) \\
\end{array}$ \\
\hline 505 & SÇKM (\%) & $\operatorname{Orta}(19.60)$ & Orta(18) & $\begin{array}{l}\text { Çok Yüksek } \\
(25.30)\end{array}$ & Düşük (19.30) & Orta (18.20) \\
\hline 506 & Asitlik $\{\mathrm{g} / \mathrm{l})$ & Yüksek (9) & Orta (8) & Düşük (7) & Yüksek (8) & Orta (7) \\
\hline- & $\begin{array}{l}\text { Olgunluk İndisi } \\
(\%)\end{array}$ & 21.77 & 22.50 & 36.14 & 24.13 & 26.00 \\
\hline \multirow[t]{2}{*}{-} & $\mathrm{pH}$ & 3.85 & 3.97 & 3.91 & 4.31 & 3.80 \\
\hline & Çekirdek Öz. & \multicolumn{5}{|c|}{ Örnek Olarak Alınan Tanelerden Çıkarılan 40 Çekirdekte Belirlenen Özellikler } \\
\hline $242-1$ & Boy $(\mathrm{mm})$ & $\begin{array}{l}\text { Uzun } \\
(6.70 \pm 0.17)\end{array}$ & $\begin{array}{l}\text { Uzun } \\
(6.92 \pm 0.07)\end{array}$ & $\begin{array}{l}\text { Uzun } \\
(7.16 \pm 0.06) \\
\end{array}$ & $\begin{array}{l}\text { Çok Uzun } \\
(7.45 \pm 0.08)\end{array}$ & $\begin{array}{l}\text { Orta } \\
(6.10 \pm 0.27)\end{array}$ \\
\hline
\end{tabular}


ÇOMÜ Zir. Fak. Derg. (COMU J. Agric. Fac.)

2020: 8 (1): 61-72

ISSN: 2147-8384 / e-ISSN: 2564-6826

doi: $10.33202 /$ comuagri.595158

\begin{tabular}{|l|l|l|l|l|l|l|}
\hline $242-2$ & En(mm) & $\begin{array}{l}\text { Çok Enli } \\
(4.26 \pm 0.13)\end{array}$ & $\begin{array}{l}\text { Çok Enli } \\
(4.16 \pm 0.06)\end{array}$ & $\begin{array}{l}\text { Çok Enli } \\
(4.34 \pm 0.04)\end{array}$ & $\begin{array}{l}\text { Cok Enli } \\
(4.23 \pm 0.07)\end{array}$ & $\begin{array}{l}\text { Orta } \\
(2.90 \pm 0.25)\end{array}$ \\
\hline 243 & A ğırlık(mg) & $\begin{array}{l}\text { A ğır } \\
(61.10 \pm 0.005)\end{array}$ & $\begin{array}{l}\text { Orta } \\
(52.30 \pm 0.001)\end{array}$ & $\begin{array}{l}\text { Ăgr } \\
(65.70 \pm 0.001)\end{array}$ & $\begin{array}{l}\text { Ağır } \\
(67.10 \pm 0.003)\end{array}$ & $\begin{array}{l}\text { Orta } \\
(54.60 \pm 0.002)\end{array}$ \\
\hline
\end{tabular}

Çizelge 1. Üzüm Çeşitlerinde İncelenen Organlara İlişkin Ampelografik Bulgular (devam)

\begin{tabular}{|c|c|c|c|c|c|c|}
\hline OIV & $\begin{array}{l}\text { İncelenen } \\
\text { Özellikler }\end{array}$ & Zeyti & Zeynebi & Bahdo & Misabık & Mazrone \\
\hline Kod No & Çubuk Öz. & \multicolumn{5}{|c|}{ Dinlenme Döneminde 10 Çubukta Boğum ve Boğum aralarında İncelenen Özellikler } \\
\hline 101 & Enine Kesit & Yuvarlak & Yuvarlak & Basık Oval & Basık Oval & Yuvarlak \\
\hline \multirow[t]{2}{*}{103} & Ana Renk & Sarımsı Kah. & Sarımsı Kah. & Sar1 & Kırmızımsı Kah. & Kırmızımsı Kah. \\
\hline & Çiçek Salkımı Öz. & \multicolumn{5}{|c|}{ Çiçeklenme Döneminde 10 Salkımda Belirlenen Özellikler } \\
\hline 151 & Çiçek Yapısı & Erdişi & Erdişi & Erdişi & Erdişi & Erdişi \\
\hline 152 & $\begin{array}{l}\text { İlk Salkımın } \\
\text { Çıktığı Boğum }\end{array}$ & 1-2. Boğum & 3-4. Boğum & $\begin{array}{l}\text { 5.Boğum ve } \\
\text { Yukarısı }\end{array}$ & $\begin{array}{l}\text { 5. Boğum ve } \\
\text { Yukarıs1 }\end{array}$ & 3-4. Boğum \\
\hline \multirow[t]{2}{*}{153} & Salkım/Göz & 1.1.-2. Salkım & 0-1. Salkım & 1-3. Salkım & 1.1-2.Salkım & 1.1-2. Salkım \\
\hline & Salkım Öz. & \multicolumn{5}{|c|}{ Derim Döneminde 10 Salkımda Belirlenen Özellikler } \\
\hline 202 & $\begin{array}{l}\text { Salkım Büyüklüğü } \\
\left(\mathrm{cm}^{2}\right)\end{array}$ & $\begin{array}{l}\text { Küçük } \\
(194.65 \pm 9.20)\end{array}$ & $\begin{array}{l}\text { Çok Küçük } \\
(133.6 \pm 8.46)\end{array}$ & $\begin{array}{l}\text { Büyük } \\
(252.08 \pm 18.77)\end{array}$ & $\begin{array}{l}\text { Çok Küçük } \\
(112.15 \pm 9.0)\end{array}$ & $\begin{array}{l}\text { Orta } \\
(201.63 \pm 13.44)\end{array}$ \\
\hline 203 & Salkım Boyu (cm) & $\begin{array}{l}\text { Kisa } \\
(17.35 \pm 0.32)\end{array}$ & $\begin{array}{l}\text { Kisa } \\
(17.30 \pm 0.31)\end{array}$ & $\begin{array}{l}\text { Orta } \\
(17.98 \pm 0.78)\end{array}$ & $\begin{array}{l}\text { Kisa } \\
(13.45 \pm 0.66)\end{array}$ & $\begin{array}{l}\text { Kisa } \\
(16.78 \pm 0.52)\end{array}$ \\
\hline 204 & Salkım Sıklığı & Seyrek & Orta Sik & Sik & Sik & Orta Sik \\
\hline 206 & $\begin{array}{l}\text { Salkım Sap } \\
\text { Uzunluğu(cm) }\end{array}$ & $\begin{array}{l}\text { Orta } \\
(7.25 \pm 0.25)\end{array}$ & $\begin{array}{l}\text { Kisa } \\
(3.05 \pm 0.36)\end{array}$ & $\begin{array}{l}\text { Cok Kisa } \\
(2.55 \pm 0.23)\end{array}$ & $\begin{array}{l}\text { K1sa } \\
(3.70 \pm 0.30)\end{array}$ & $\begin{array}{l}\text { K1sa } \\
(5.90 \pm 0.26)\end{array}$ \\
\hline \multirow[t]{2}{*}{207} & Sap Odunlaşması & Zayıf & Orta & Orta & Yok & Güçlü \\
\hline & Tane Öz. & \multicolumn{5}{|c|}{ Derim Döneminde 10 Salkımdan Alınan 40 Tanede İncelenen Özellikler } \\
\hline $221-1$ & Boy $(\mathrm{mm})$ & $\begin{array}{l}\text { Orta } \\
(16.28 \pm 0.12)\end{array}$ & $\begin{array}{l}\text { Çok Uzun } \\
(23.00 \pm 0.32)\end{array}$ & $\begin{array}{l}\text { Çok Uzun } \\
(23.17 \pm 0.24)\end{array}$ & $\begin{array}{l}\text { Kisa } \\
(13.05 \pm 0.18)\end{array}$ & $\begin{array}{l}\text { Orta } \\
(16.04 \pm 0.11)\end{array}$ \\
\hline $221-2$ & $\operatorname{En}(\mathrm{mm})$ & $\begin{array}{l}\text { Orta } \\
(15.87 \pm 0.17)\end{array}$ & $\begin{array}{l}\text { Dar } \\
(11.81 \pm 0.42)\end{array}$ & $\begin{array}{l}\text { Enli } \\
(19.94 \pm 0.22)\end{array}$ & $\begin{array}{l}\text { Dar } \\
(11.90 \pm 0.19)\end{array}$ & $\begin{array}{l}\text { Orta } \\
(15.38 \pm 0.10)\end{array}$ \\
\hline 222 & İrilikte Bir örneklik & Birörnek Değil & Birörnek & Birörnek Değil & Birörnek Değil & Birörnek \\
\hline 223 & Tanenin Şekil & Yuvarlak & Sivri & Elips & Yuvarlak & Yuvarlak \\
\hline 225 & Kabuk Rengi & Yeşil-Sarı & Yeşil-Sarı & Yeşil-Sarı & Siyah & Yeşil-Sarı \\
\hline 226 & $\begin{array}{l}\text { Kabuk Rengi } \\
\text { Bir örneklik }\end{array}$ & Birörnek Değil & Birörnek & Birörnek & Birörnek & Birörnek \\
\hline- & Kabuk Kalınlığı & Kalın & İnce & Orta & İnce & İnce \\
\hline 233 & Şıra Randımanı(\%) & Orta (62.30) & Yüksek (72.50) & Orta (57.50) & Düşük (49.60) & Yüksek (65.70) \\
\hline 238 & $\begin{array}{l}\text { Tane Sap } \\
\text { Boyu(mm) }\end{array}$ & $\begin{array}{l}\text { Kisa } \\
(8.48 \pm 0.25)\end{array}$ & $\begin{array}{l}\text { Kisa } \\
(6.32 \pm 0.29)\end{array}$ & $\begin{array}{l}\text { K1sa } \\
(7.52 \pm 0.20)\end{array}$ & $\begin{array}{l}\text { Çok Kısa } \\
(4.74 \pm 0.21) \\
\end{array}$ & $\begin{array}{l}\text { K1sa } \\
(6.22 \pm 0.23)\end{array}$ \\
\hline 241 & Çekirdek Varlığ 1 & Var & Var & Var & Var & Var \\
\hline 503 & Tane Ağırlı̆̆ı(g) & $\begin{array}{l}\text { Orta } \\
(3.35 \pm 0.15)\end{array}$ & $\begin{array}{l}\text { Orta } \\
(2.70 \pm 0.09)\end{array}$ & $\begin{array}{l}\text { Çok Ağır } \\
(5.65 \pm 0.14) \\
\end{array}$ & $\begin{array}{l}\text { Çok Hafif } \\
(1.24 \pm 0.06)\end{array}$ & $\begin{array}{l}\text { Hafif } \\
(2.57 \pm 0.05)\end{array}$ \\
\hline 505 & SÇKM (\%) & Düşük (19.80) & Yüksek (20.20) & Düşük (18.50) & Düşük (17.80) & Yüksek (21.06) \\
\hline 506 & Asitlik $\{\mathrm{g} / \mathrm{l})$ & Düşük (6) & Düşük (6) & Düşük (6) & Orta (8) & Düşük (6) \\
\hline- & Olgunluk İndisi (\%) & 33.00 & 33.66 & 30.83 & 22.25 & 35.10 \\
\hline \multirow[t]{2}{*}{-} & $\mathrm{pH}$ & 3.71 & 3.78 & 3.97 & 3.81 & 3.66 \\
\hline & Çekirdek Öz. & \multicolumn{5}{|c|}{ Örnek Olarak Alınan Tanelerden Çıkarılan 40 Çekirdekte Belirlenen Özellikler } \\
\hline $242-1$ & Boy $(\mathrm{mm})$ & $\begin{array}{l}\text { Uzun } \\
(7.30 \pm 0.05)\end{array}$ & $\begin{array}{l}\text { Çok Uzun } \\
(7.59 \pm 0.05)\end{array}$ & $\begin{array}{l}\text { Çok Uzun } \\
(8.20 \pm 0.09) \\
\end{array}$ & $\begin{array}{l}\text { Uzun } \\
(6.33 \pm 0.05)\end{array}$ & $\begin{array}{l}\text { Uzun } \\
(7.24 \pm 0.05)\end{array}$ \\
\hline $242-2$ & $\operatorname{En}(\mathrm{mm})$ & $\begin{array}{l}\text { Çok Enli } \\
(4.32 \pm 0.05)\end{array}$ & $\begin{array}{l}\text { Enli } \\
(3.95 \pm 0.10)\end{array}$ & $\begin{array}{l}\text { Çok Enli } \\
(4.68 \pm 0.07)\end{array}$ & $\begin{array}{l}\text { Çok Enli } \\
(4.12 \pm 0.04)\end{array}$ & $\begin{array}{l}\text { Çok Enli } \\
(4.54 \pm 0.04)\end{array}$ \\
\hline 243 & Ağırlık(mg) & $\begin{array}{l}\text { Orta } \\
(53.90 \pm 0.001)\end{array}$ & $\begin{array}{l}\text { Orta } \\
(57.90 \pm 0.001)\end{array}$ & $\begin{array}{l}\text { Çok Ağır } \\
(83.70 \pm 0.002) \\
\end{array}$ & $\begin{array}{l}\text { Orta } \\
(49.20 \pm 0.001)\end{array}$ & $\begin{array}{l}\text { Cok Ağır } \\
(75.60 \pm 0.001) \\
\end{array}$ \\
\hline
\end{tabular}

Öz.: Özellik Sar.: Sarımsı Kah.: Kahverengi Brz.Bn.: Bronz benekli Kır.: Kırmızı 
ÇOMÜ Zir. Fak. Derg. (COMU J. Agric. Fac.)

2020: 8 (1): 61-72

ISSN: 2147-8384 / e-ISSN: 2564-6826

doi: 10.33202/comuagri.595158

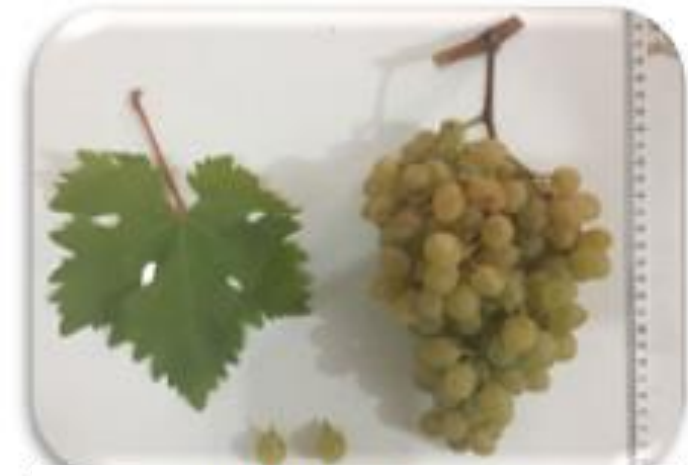

Şekil 1. Kerküş üzüm çeşidi

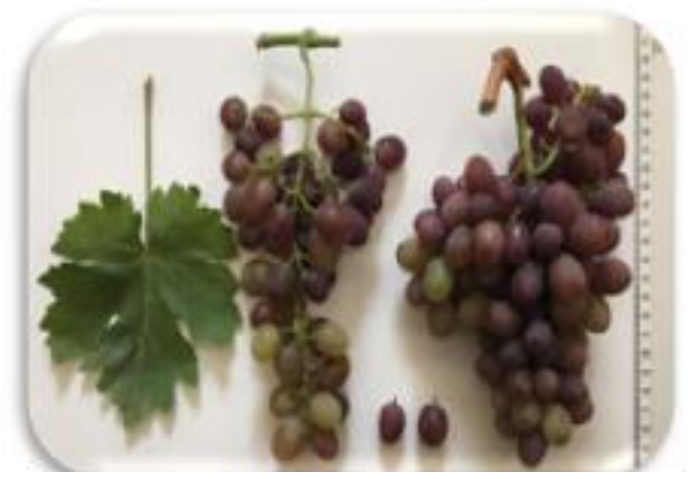

Şekil 3. Tayifi üzüm çeşidi

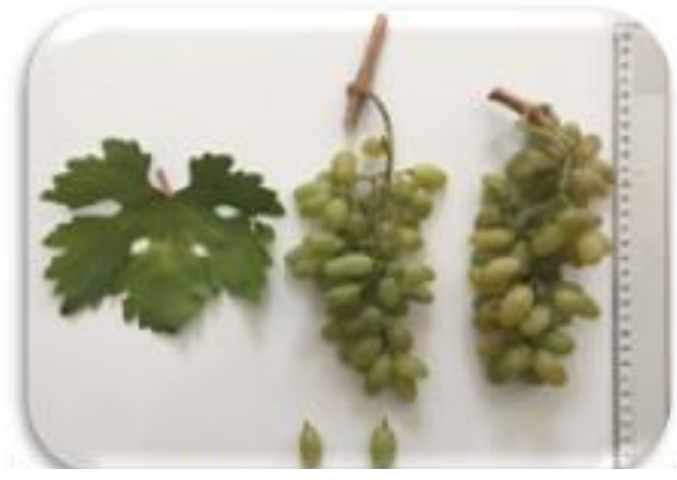

Şekil 5. Zeynebi üzüm çeşidi

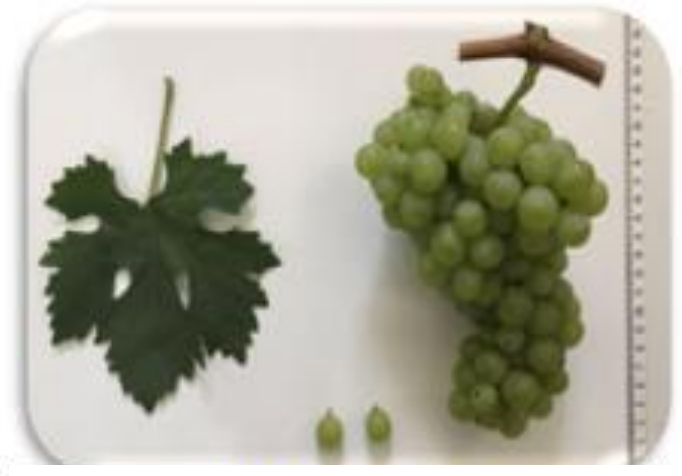

Şekil 2. Haseni üzüm çeşidi

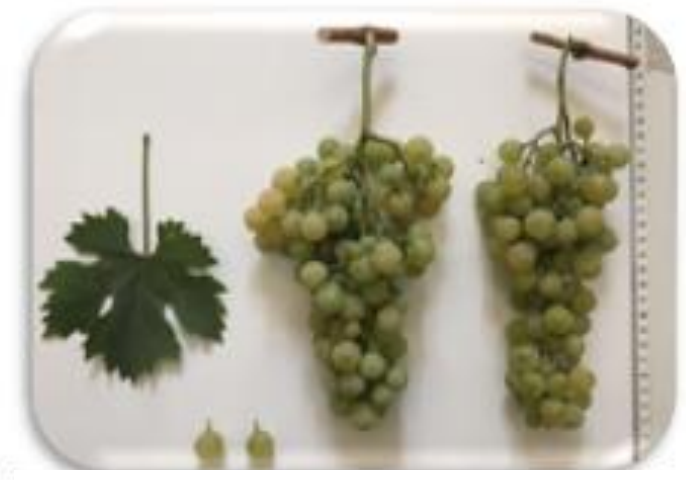

Şekil 4. Zeyti üzüm çeşidi

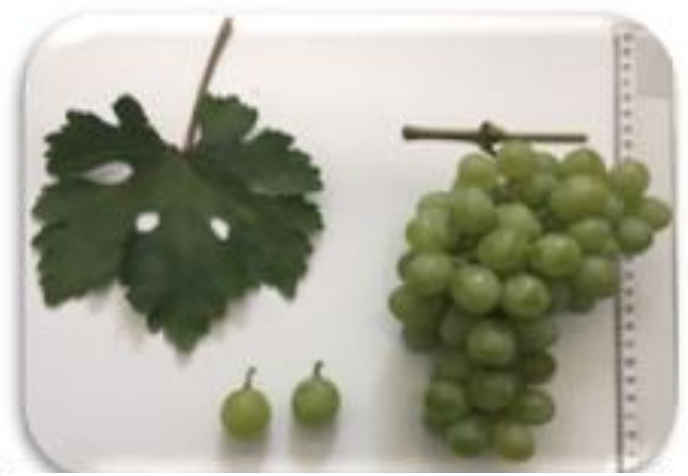

Şekil 6. Bahdo üzüm çeşidi 
ÇOMÜ Zir. Fak. Derg. (COMU J. Agric. Fac.)

2020: 8 (1): 61-72

ISSN: $2147-8384$ / e-ISSN: 2564-6826

doi: 10.33202/comuagri.595158

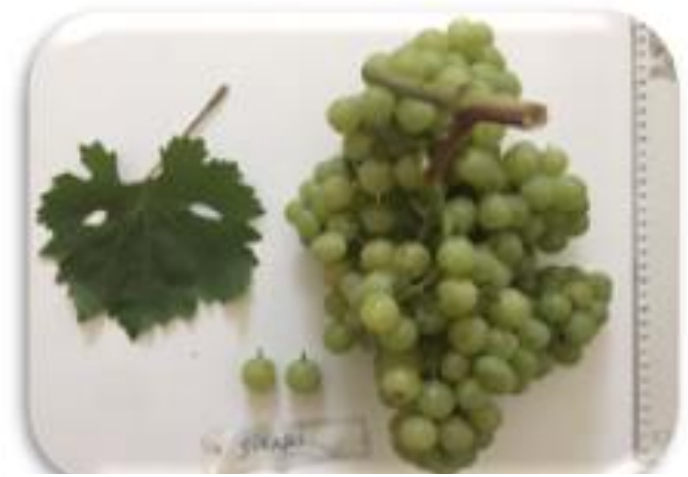

Şekil 7. Şikari üzüm çeşidi

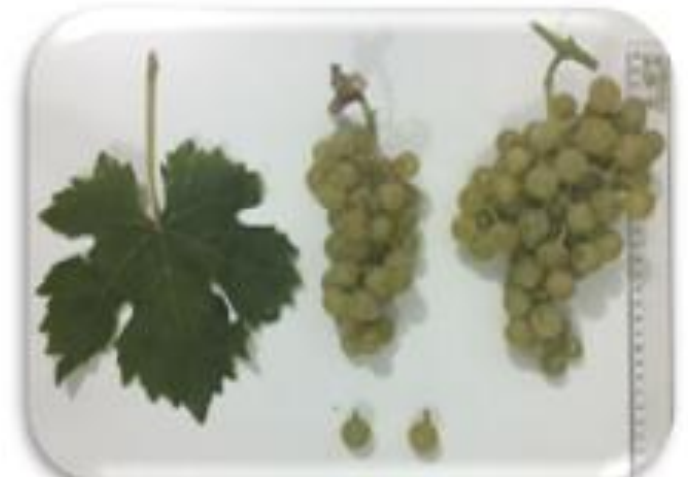

Şekil 9. Gawre üzüm çeşidi

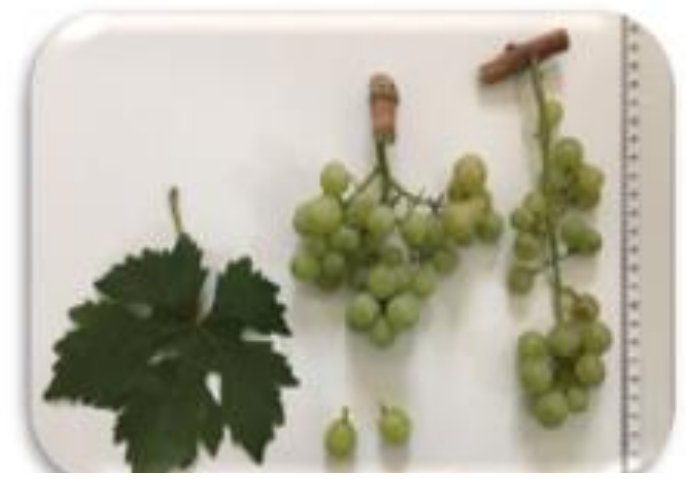

Şekil 11. Beytilhimam üzüm çeşidi

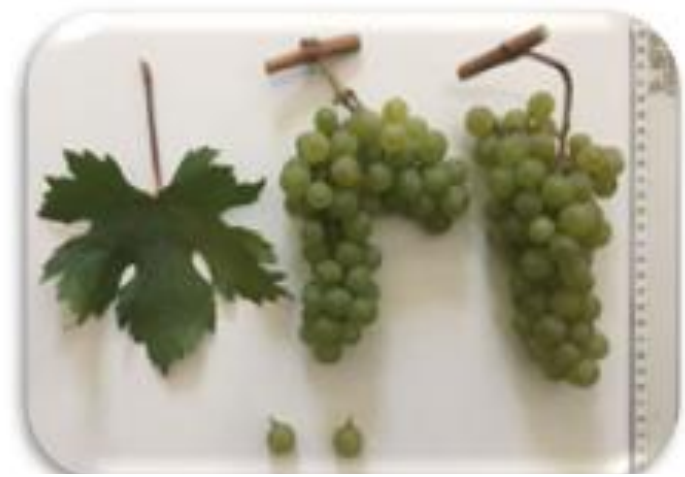

Şekil 8. Sinceri üzüm çeşidi

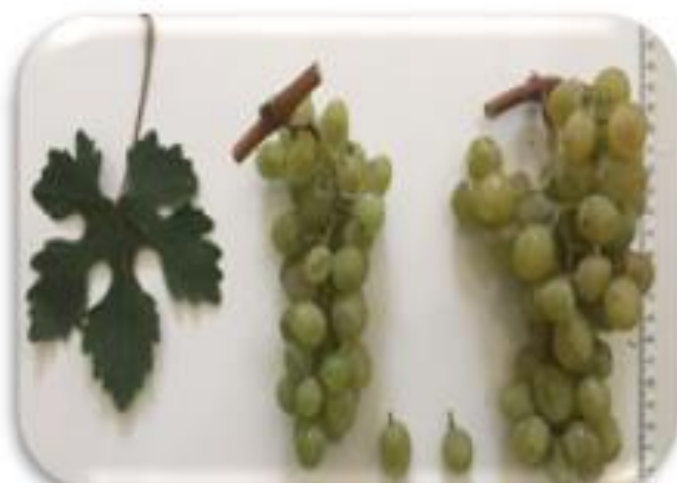

Şekil 10. Nasiri üzüm çeşidi

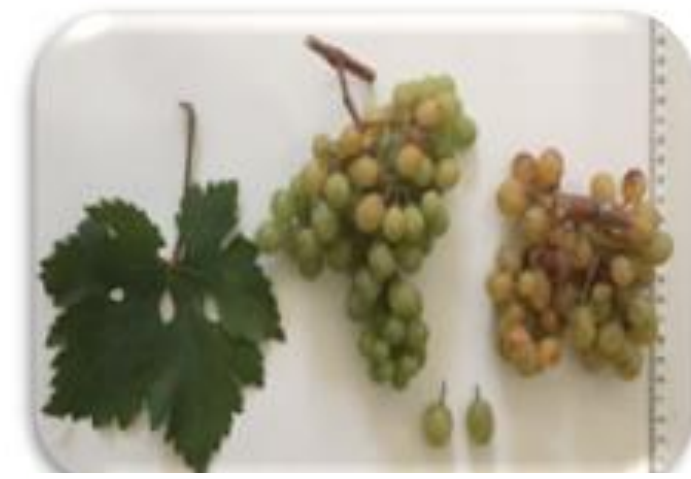

Şekil 12. Goglani üzüm çeşidi 
ÇOMÜ Zir. Fak. Derg. (COMU J. Agric. Fac.)

2020: 8 (1): 61-72

ISSN: 2147-8384 / e-ISSN: 2564-6826

doi: 10.33202/comuagri.595158

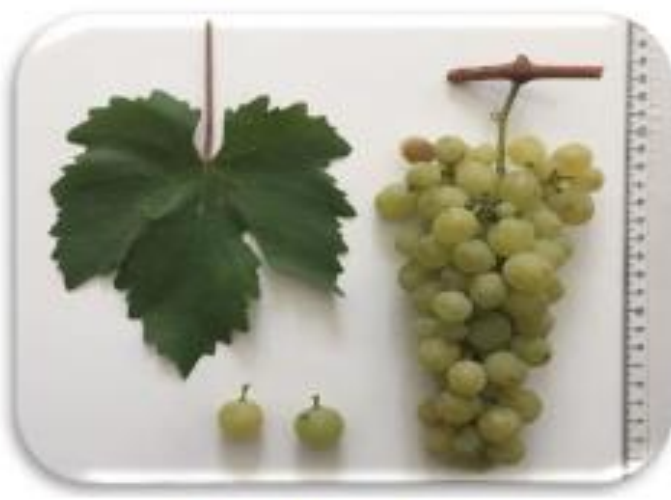

Şekil 13. Bakari üzüm çeşidi

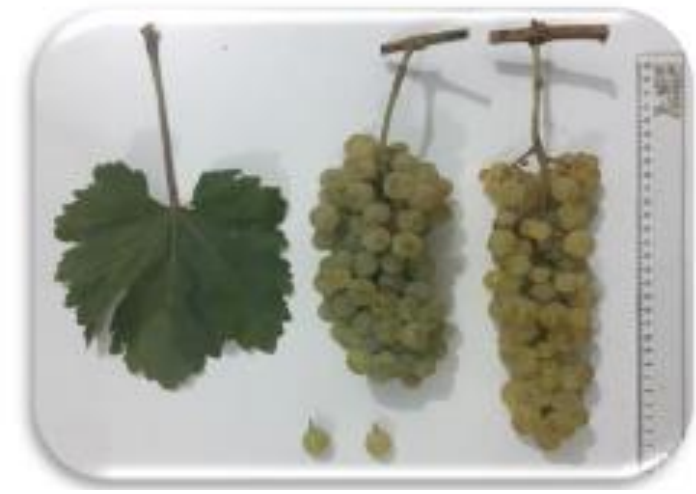

Şekil 15. Zerine üzüm çeşidi

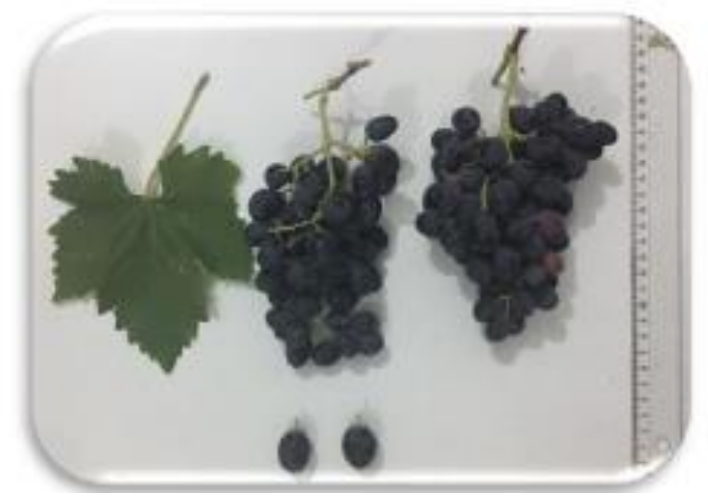

Şekil 17. Raşe kewnar üzüm çeşidi

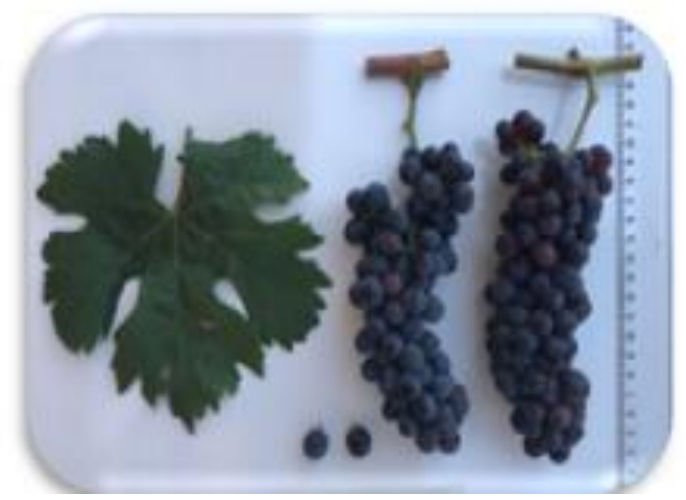

Şekil 19. Misabık üzüm çeşidi

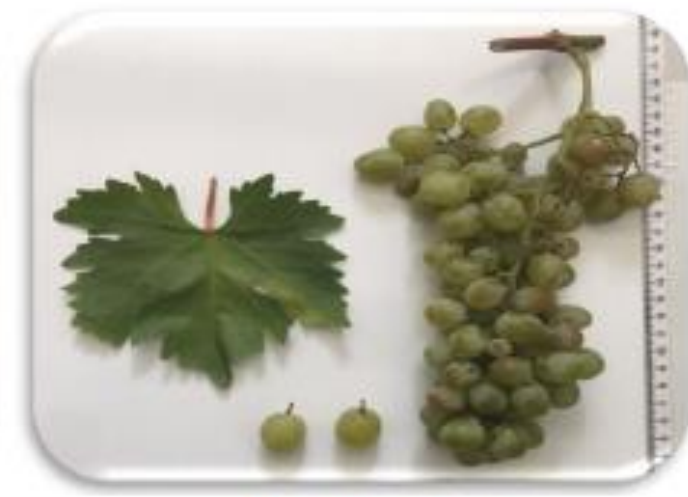

Şekil 14. Bilbizeki üzüm çeşidi

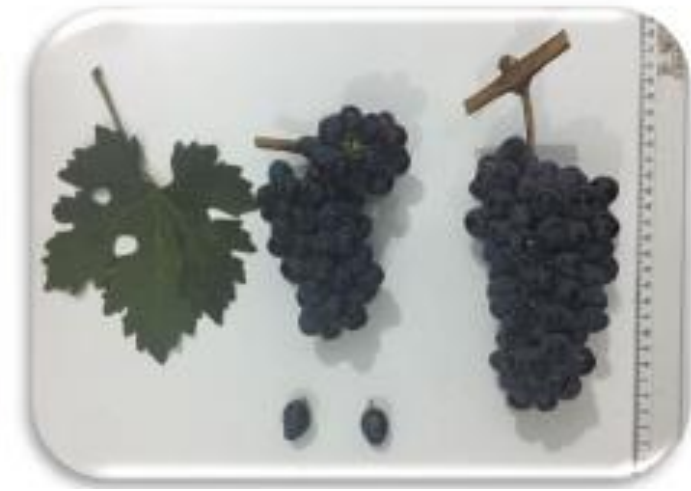

Şekil 16. Raşe gurnik üzüm çeşidi

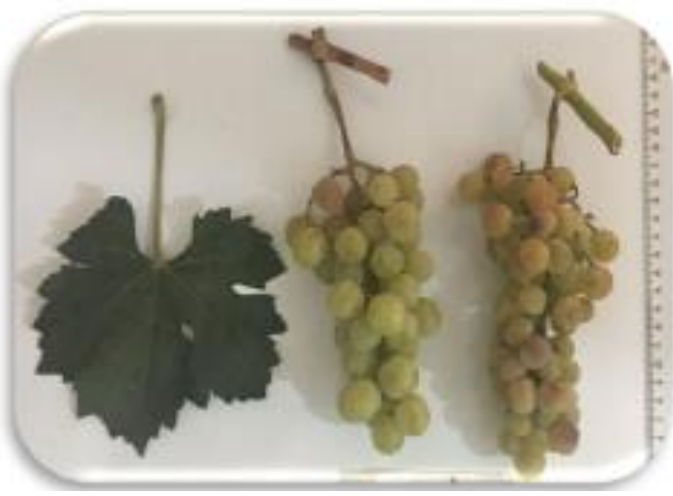

Şekil 18. Payizi üzüm çeşidi

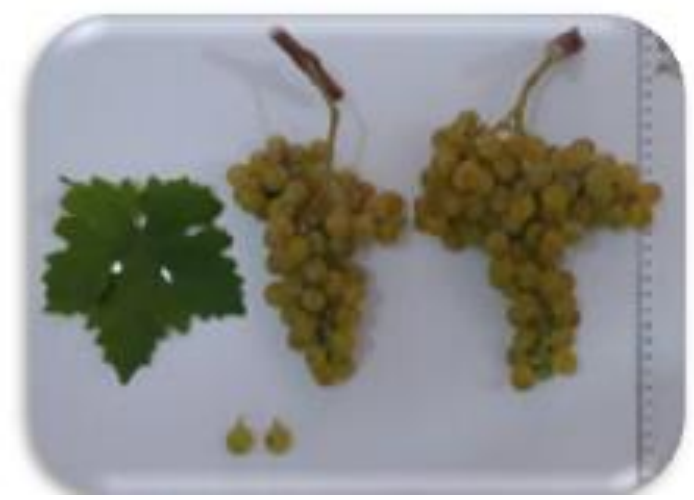

Şekil 20. Mazrone üzüm çeşidi 


\section{Sonuç}

Üzüm çeşitlerinin gruplandırılmasında ve tanımlanmalarında kullanılan renk, şekil, irilik, irilik ve renkte bir örneklik, salkım sıklığı, en, boy, kabuk kalınlığı, pH, kuru madde ve asitlik, özellikle irilik, en, boy gibi ölçüm ve tartım yapılan özelliklerin üzüm çeşidi yanında yetiştiği çevre şartlarına, bakım işlemlerine, arazinin konumu ve zamana bağlı olarak önemli farklılıklar gösterebildikleri belirlenmiştir. Buna karşıllk çekirdek varllğ 1 ve çiçek tipinin, çevre vb. unsurlardan etkilenmeyip tamamen çeşit özelliği olarak kendisini gösterdiği tespit edilmiştir. Şekil yönünden ele alındığında tanelerde oluşan değişimlerin diğer organlara ve renge nazaran daha az olduğu; renk bakımından ise çeşitlerin tanımlanmasında özellikle antosiyaninlerin varlığı ve yoğunluğunun önemli olduğu gözlemlenmiştir.

Çalışmada çeşitlerin tanımlanmasında kullanılan metot bazında değerlendirme yapılacak olursa; biyokimyasal yöntemler (moleküler markörler) çeşitlerin tanımlanmasında daha güvenilir metot olarak kabul edilmekle birlikte araştırıcılar biyokimyasal ve klasik yöntemlerin bir arada yapılmasının gerekliliğini vurgulamaktadırlar (Sabır, 2008). Dolayısıyla çeşitlerin tanımlamada her iki grupta yer alan yöntemlerin kullanılmasının daha doğru ve sağlıklı sonuçlar verebileceği düşünülmektedir.

Not: Yüksek Lisans tezinden üretilmiştir.

\section{Kaynaklar}

Altın, H., 1991. Çukurova Üniversitesi Ziraat Fakültesi Araştırma Bağında Yetiştirilen Bazı Üzüm Çeşitlerinde Ampelografik Özellikler ve Fenolojik Safhaların Belirlenmesi Üzerinde Bir Araştırma. Ç.Ü. Fen Bil. Enst., Bahçe Bit. Anabilim Dalı, Yük. Lisans Tezi, 15Is.

Anonymous, 1983. Descriptors for Grape, International Board for Plant Genetic Resources (IBPGR) secretariat, Roma, 93.

Anonymous, 1989. Minimal Descriptor List for Grapevine Varieties. 5th International Symposium on Grape Breeding, Geilwerlerhof.

Anonymous, 2001. 2. Edition of the OIV Descriptor List for Grape Varieties and Vitis Species Organisation Internationale de la Vigne et du Vin, Paris.

Anonim, 2019. https:// biruni.tuik. gov.tr/medas/?kn=92\&locale=tr 16.5.2019

Barış, C., Gürnil, K., 1991. Üzüm çeşitlerinde (V. vinifera L.) çekirdeksizliğin kalıtımı. Tarım ve Köyişl. Bak., Tar. Araş. Gen. Müd. Atatürk Bahçe Kültürleri Araş. Enst.,Yalova, Bahçe. 20(1-2): 87-100

Calo, A., Costacurta, A., Cancellier, S., Forti, R., 1991. Verdicchio, Bianco, Trebbiano di Soave. A Single Grapevine Variety. Vignevini, 18(11): 45-48.

Cooke, G.M., Berg, H.W., 1983. A Re-Examination of varietal table wine processing practices in California. I. Grape Standards. Grape and Juice Treatment And Fermentation. Am. J. EnoL Vitic. 34(4): 249-256.

Çoban, H., Küey, E., 2006. Manisa'da(Yuntdağı) yetiştirilen üzüm çeşitlerinin ampelografik özelliklerinin belirlenmesi üzerine araştırmalar. Ege Üniversitesi, Ziraat Fakültesi Dergisi. 2006, 43(2):41- 52.

Dağl1, S., 1962. Muhtelif üzüm çeşitleri arasında melezleme suretiyle erken yeni sofralık çeşitlerin elde edilmeleri üzerinde araştırmalar. Tar. Bak. Zir. İşl. Gn. Müd., Yayınları, İstanbul, C-103,63s.

Demir, İ., 1987. Ankara Şartlarında Yetiştirilen Yabancı Kökenli Bazı Üzüm Çeşitlerinin Ampelografik Özelliklerinin Belirlenmesi Üzerine Araştırmalar. Ankara Üniversitesi, fen Bil. Ens. Müd., Bahçe Bit. Anabilim Dalı, Yüksek Lisans Tezi, 98s.

Dilli, Y., Ünal, A., Kesgin, M., İnan, M.S., Söylemezoğlu, G., 2014. Comparison of ampelographic characteristics of some important grape varieties are grown in the Aegean Region, rootstock and clones. Turkish Journal of Agricultural and Natural Sciences Special Issue: 2: 1546-1553.

Dursun, A., 1994. Delice İlçesi Bağcılığı ve Yetiştirilen Üzüm Çeşitlerinin Ampelografik Özellikleri. Ankara Üniversitesi, Fen Bil. Enst., Bahçe Bit. Anabilim Dalı, Yük. Lisans Tezi, 91s.

Ergenoğlu, F., 1985. Çukurova Şartlarında Yetişen Yabancı Kökenli Erkenci Üzüm Çeşitlerinin Adaptasyonu Üzerinde Bir Araştırma. TÜBİTAK Tarım ve Ormancılık Araştırma Grubu, Akdeniz Bahçe Bitkileri Araştırma Ünitesi, Ç.Ü.Zir. Fak. Bahçe Bit. Böl., Adana, Proje No: ABBAÜ- 18, 30s.

Fanizza, G., 1982. Factor analyses for the choice of a criterion ofwine grape (V. V.) maturity in warm regions. Vitis. 21(4): 334-336.

Fidan, Y., 1975. Ziraat Fakültesi fermantasyon teknolojisi kürsüsü koleksiyon bağında yetiştirilen papazkarası, öküzgözü ve merzifon karası üzüm çeşitlerinin ampelografik vasıfları üzerinde araştırmalar. Ankara Üni. Zir. Fak. Derg. 24: 67-95.

Fidan, Y., 1985. Özel Bağcılık. Ankara Üniversitesi, Ziraat Fakültesi Yayınları, No: 930, Ders Kitabı No: 265, 400s. Ankara. 
Galet, P., 1956-1964. Cepages Et Vignobles De France. Tome 1-1V, Imprimerie Paul Dehan, Montpellier.

Gider, S., 1995. Kalecik Karası Üzüm Çeşidinin Klon Seleksiyonuyla Elde Edilmiş Klonlarının Ankara Şartlarında Ampelografik Özelliklerinin Saptanması Üzerine Bir Araştırma. Ankara Üniversitesi, Fen Bilimleri Enstitüsü, Bahçe Bit. Anabilim Dalı, Doktora Tezi, 148s.

Gürsöz, S., 1993. GAP Alanına Giren Güneydoğu Anadolu Bölgesi Bağcılı̆̆ı ve Özellikle Şanlıurfa İlinde Yetiştirilen Üzüm Çeşitlerinin Ampelografik Nitelikleri İle Verim ve Kalite Unsurlarının Belirlenmesi Üzerinde Bir Araştırma. Çukurova Üniversitesi, Fen Bil. Enst., Bahçe Bit. Anabilim Dalı, Doktora Tezi, $363 \mathrm{~s}$.

Kara, Z., 1990. Tokat Yöresinde Yetiştirilen Üzüm Çeşitlerinin Ampelografik Özelliklerinin Belirlenmesi Üzerinde Araştırmalar. Ankara Üniversitesi, Fen Bil. Enst., Bahçe Bit. Anabilim Dalı, Doktora Tezi,317s.

Marasalı, B., 1986. Ankara Şartlarında Yetiştirilen Bazı Yerli Standart Üzüm Çeşitlerinin Ampelografik Özelliklerinin Belirlenmesi Üzerinde Araştırmalar. Ankara Üniversitesi, Fen Bil. Enst., Bahçe Bit. Anabilim Dalı, Yüksek Lisans Tezi, 87s.

Morton, L.T., 1979. A Practical Ampelography (Translated and Adapted from P. Galet). Cornel University Pres, Ithaca and London. 248.

Oraman, N., 1937. Ankara vilayeti bağcılığı ve Ankara'da yetişen başlıca üzüm çeşitlerinin ampelografisi. Yüksek Ziraat Ens. Sayı: 61, Ankara,206s.

Oraman, N., 1959. Ampelografi. Ankara Üniversitesi, Ziraat Fakültesi Yayın No:154, 154s. Ankara.

Özbek, S., 1951. Baba çeşitlerin çavuş üzümünün meyve vasıfları üzerine doğrudan doğruya tesiri (Metaxenie). Ankara Üniversitesi, Ziraat Fakültesi, 1951 Yıllığı, Ankara, s.142-165

Özdemir, G., Bayhan, Y.D., 2018. Bazı Sofralık Üzüm Çeşitlerinin Diyarbakır Ekolojik Koşullarındaki Salkım, Tane ve Şıra Özelliklerinin Belirlenmesi. International Congress on Agriculture and Animal Sciences (ICAGAS 2018) (Tam Mestin Bildiri/Sözlü Sunum). Dicle Üniversitesi Ziraat Fakültesi Bahçe Bitkileri Bölümü, Diyarbakır / Türkiye, 7-9 Kasım 2018.

Sabır, A., 2008. Bazı Üzüm Çeşit Ve Anaçlarının Ampelografik ve Moleküler Karekterizasyonu. Çukurova Üniversitesi, Fen Bilimleri Enstitüsü, Bahçe Bit. Anabilim Dalı, Doktora Tezi, 154s.

Şehirali, S., Özgen, M., 1987. Bitkisel Gen Kaynakları. Ankara Üniversitesi, Ziraat Fakültesi Yayın No: 1020, Ders Kitabi: 294, 239s. Ankara.

Uzun, H.İ., 1986. Bazı Üzüm Çeşitlerinin Ampelografik Özellikleri, Kateşol Oksidaz İzoenzim Bantlarından Teşhisleri ve Sıcaklık Toplamları Üzerinde Araştırmalar. Ege Üniversitesi, Ziraat Fakültesi, Bahçe Bitkileri Anabilim Dali, Doktora Tezi, 176s.

Ünal, M.S., Ergenoğlu F., 2001. Malatya ve Elazığ illeri bağcılı̆̆ı ile Malatya ilinde yetiştirilen üzüm çeşitlerinin ampelografik özelliklerinin belirlenmesi Üzerine Araştırmalar. Çukurova Üniversitesi Ziraat Fakültesi Dergisi, 16(2), 1-8. (Yayın No: 5103542)

Ünal, M.S., 2018. İdil Bölgesi Üzüm Çeşitlerinin Salamura Yaprak Yapımına Uygunluğunun Araştırılması.Şehri Nuh Uluslararası Multidisipliner Çalışmalar Kongresi, 1, 6 (Tam Metin Bildiri/Sözlü Sunum) (Yayın No:4396916).

Winkler, A.J., Cook, J.A., Klieer, W.M., Lider, L.A., 1974 . General Viticulture. Univ. of California. Pres, Berkeley 